The Open Biomedical Engineering
Journal
CrossMark
Content list available at: www.benthamopen.com/TOBEJ/
DOI: $10.2174 / 1874120701610010115$

\title{
RETRACTION
}

\section{Retraction Notice: 3D DWT-DCT and Logistic MAP Based Robust Watermarking for Medical Volume Data}

Jingbing $\mathrm{Li}^{1}$, Yaoli Liu ${ }^{1}$ and Jiling Zhong ${ }^{2, *}$

${ }^{\prime}$ College of Information Science and Technology, Hainan University, Haikou, China, 570228

${ }^{2}$ Department of Computer Science, Troy University, Alabama, USA, 36082

\section{RETRACTION}

The Publisher and Editor have retracted this article [1] in accordance with good ethical practices. After a thorough investigations we believe that the peer review process was compromised. The article was published on-line on 31-12-2014.

\section{REFERENCES}

[1] J. Li, Y. Liu, and J. Zhong, "3D DWT-DCT and logistic MAP based robust watermarking for medical volume data", Open Biomed. Eng. J., vol. 8, pp. 131-141, 2014

(C) Li et al.; Licensee Bentham Open.

This is an open access article licensed under the terms of the Creative Commons Attribution-Non-Commercial 4.0 International Public License (CC BY-NC 4.0) (https://creativecommons.org/licenses/by-nc/4.0/legalcode), which permits unrestricted, non-commercial use, distribution and reproduction in any medium, provided the work is properly cited.

\footnotetext{
* Address correspondence to this author at the Department of Computer Science, Troy University, Alabama, USA, 36082 ; Tel: 334-670-3388; Fax:334-670-3673; -mail:jzhong@troy.edu
} 